\title{
Learning Development Through Local Identity and Multicultural: Papuan-Ness High School Students Jayapura
}

\author{
Susanto T. Handoko ${ }^{1}$, Wasino Wasino ${ }^{2}$, Masrukhi ${ }^{3}$, Hamdan Tri Atmaja ${ }^{4}$ \\ ${ }^{1,2,3,4}$ Graduate School Universitas Negeri Semarang \\ ${ }^{1}$ Corresponding email: susantoth15@gmail.com.
}

\begin{abstract}
The main problem of history learning in Papua is the alienation of students with the content lessons. Because most of the historical content is far from the reality of everyday life of the students because of the setting and locality generally from outside Papua. Therefore, history learning must emphasize the social and cultural aspects of Papua. This study aims to describe Papuan-ness identity of high school students in Jayapura. This study was conducted by using a qualitative research design. Furthermore, the subjects of this research included the native Papuan high school students and the high school students from mixed marriage (Papuan and non-Papuan) in Jayapura. Data collection employed observation, interviews, and the document method. Particularly, data analysis technique used interactive analysis. The result showed that there were two categories of Papuan-ness identity of the high school students in Jayapura: local identity and multicultural. Development of learning history in Papua in accordance with local identity and multicultural should be done immediately. Materials on local identity make history education more meaningful and cultivate students critical power.
\end{abstract}

Keywords: learning development, local identity, multicultural, papuan-ness, high school students.

\section{Introduction}

The rapid development of science, technology and information now needs attention from the educational point of view, including history learning. History learning are required to contribute in the development process of the Indonesian nation both now and in the future. However, history learning is still often considered a past that no longer has relevance to the present or the future. History learning are still considered unimportant and neglected in the national education system. History learning tends to be just a process of tranfer of knowledge so that as education praxis can not be actualized optimally (Pramono, 2012: 239-240). This led to history learning being a boring and less useful subject (Nafi'ah., \& Utami, 2017: 103; Putro, 2012: 208). Another factor is that most teachers still tend to use expository learning strategies; the use of resources and learning media are less varied (Sutrisna, 2012: 48; Wahyuni, 2012: 119; Sutiyah, 2013: 121).

According to Supriatna (2012: 122) History not only emphasizes national development but also incorporates local issues that are more relevant to the interests of students. Historical learning like this can be presented using various approaches by making students as active learners as well as the perpetrators of history in his era. Referring to Kartodirdjo's opinion (Suryani, 2013: 209) history learning should not merely serve to provide historical knowledge as a collection of historical fact information but also aims to awaken learners or raise awareness of its history. Meanwhile, Soedjatmoko (Agung, 2014: 127) history learning should be organized as a common avenue of educators and learners. In this conception, it is not a rote fact but a joint research between educators and learners. The issue of history learning is of course also a problem for education stakeholders in Papua. In the context of Papua the problem can be identified more specifically from both the student side, the history teacher, and the content of the lesson.

The main problem of history learning in Papua is the alienation of students with the content lessons. Because most of the historical content is far from the reality of everyday life of the students because of the setting and locality generally from outside Papua. Therefore, history learning must emphasize the social and cultural aspects of Papua. Historical education not only emphasizes national development, but also incorporates local issues that are more relevant to student interests. Learning history like this makes students as an active learner as well as a perpetrator of history in his era. Thus, the research question is 'How is Papuan-ness identity of high school students in Jayapura? The purpose of the research was to analyze Papuan-ness 
identity of high school students in Jayapura. Materials on local identity (Papuan-ness) make history education more meaningful and cultivate students critical power.

\section{Method}

This study was a qualitative explanative research based on the facts in the field (Creswell, 2014). Triangulation technique was applied by conducting: (1) an observation of social situation in Jayapura; (2) a deep interview with six respondents from tenth, eleventh, and twelfth grade of the native Papuan high school students and other six respondents from tenth, eleventh, and twelfth of Papuan high school students of the mix marriage between native Papuan and nonPapuan in two public high schools, SMA Negeri 1 and SMA Negeri 2, as well as two private schools, SMA Muhammadiyah and SMA Taruna Bakti in Jayapura; (3) documentation, including literature resources on Papuan-ness, ethno-nationalims and multicultural; (4) inductive data analysis which constructed theory from the data in the field; (5) a purposive sampling technique was used to determine the informants from the native Papuan students and the mix Papuan students. All data gathered, especially no. 2 was used to answer the research question on how Papuanness identity of the high school students in Jayapura. Therefore, the finding emphasized on interpretation, or meaning rather than generalization on broad analysis. Researchers use the main frame of reference of Bourdieu's Piere theory about the relationship between the concepts of habitus, arena, and capital (Adib,2012; Bourdieu, 2016; Harker., Mahar., \& Wilkes, (Ed.), 2009; Setyawan, 2017: 1819); and supported by Albert Bandura's theory of human behavior in the context of reciprocal interactions between cognitive (person), behavior, and environment (Schunk, 2012: 160-168).

\section{Results and Discusiion}

\subsection{Papuan-ness Indigenous Papuan High School Students in Jayapura}

Papuan-ness indigenous Papuans High School Students in Jayapura based on five indicators (ethnics, races, language, ideology and symbols) are grouped into two categories (Afwan, 2015; Anwar \& Cangara, 2016; Pamungkas, 2015 \& 2016; Supriyono, 2014; Trajano, 2010; Widjojo, (Ed.), 2009: Zuhdi, 2017): (1) Local Identity (Ethno-Nationalism), and (2) Multicultural. Local Identity meaning the growing ethno-nationalism of tribes in Papua and spirit the formation of awareness of ethnic identity. The ethnic identity is stronger than the Papuan identity. Multicultural meaning diversity of Papua: language, culture, ethnicity and ideology - spirit the unity of the Papuan people.

Based on Table 1, First, the Local Identity Category or Ethno-Nationalism attached to Robert and Viktor. Based on ethnicity, the two students came from the Central Mountain region of Papua namely Wamena (Jayawijaya) and Pegunungan Bintang. In terms of race, both students are Melanesian race which is the original race of Papua. The local languages they use in the family environment, hostel/dormitories (Viktor), and social environment in group of both students. From the aspect of ideology, Robert adheres to Catholicism, while Viktor embraces Ptotestan religion. The identity of Christianity provides a strong legitimacy to the identity of the Papuans - the Indigenous Papuans is identical with Christianity. The tribal identity of both students is very prominent. The symbol attached to them is the use of Papuan batik cloth as one of the official school uniforms in Jayapura. Other symbols known to the two students are honai, noken, tifa, and typical food of Papua (Central Mountain) that is hipere. 
Table 1 Papuan-ness Indigenous Papuan High School Students in Jayapura

\begin{tabular}{|c|c|c|c|c|c|c|}
\hline \multirow[t]{3}{*}{ INDICATOR } & \multicolumn{6}{|c|}{ CATEGORY } \\
\hline & \multicolumn{2}{|c|}{$\begin{array}{c}\text { Local Identity } \\
\text { (Ethno-Nationalism) }\end{array}$} & \multicolumn{4}{|c|}{ Multicultural } \\
\hline & & & Nancy & Nando & Obed & Richard \\
\hline Ethnics & $\begin{array}{l}\text { Papua } \\
\text { (Wamena) }\end{array}$ & $\begin{array}{l}\text { Papua } \\
\text { (Pegunung } \\
\text { an } \\
\text { Bintang) }\end{array}$ & $\begin{array}{l}\text { Papua } \\
\text { (Manokwari } \\
\text { / Biak) }\end{array}$ & $\begin{array}{l}\text { Papua } \\
\text { (Ayamaru) }\end{array}$ & $\begin{array}{l}\text { Papua } \\
\text { (Bonggo/ } \\
\text { Sarmi) }\end{array}$ & $\begin{array}{l}\text { Papua (Port } \\
\text { Numbay) }\end{array}$ \\
\hline Races & Melanesian & $\begin{array}{l}\text { Melanesia } \\
\mathrm{n}\end{array}$ & Melanesian & Melanesian & Melanesian & Melanesian \\
\hline \multirow[t]{2}{*}{ Language } & $\begin{array}{l}\text { Regional } \\
\text { languages }\end{array}$ & $\begin{array}{l}\text { Regional } \\
\text { languages }\end{array}$ & $\begin{array}{l}\text { Regional } \\
\text { languages }\end{array}$ & $\begin{array}{l}\text { Regional } \\
\text { languages }\end{array}$ & $\begin{array}{l}\text { Regional } \\
\text { languages }\end{array}$ & $\begin{array}{l}\text { Regional } \\
\text { languages }\end{array}$ \\
\hline & $\begin{array}{l}\text { are spoken } \\
\text { at home, } \\
\text { hostel, } \\
\text { social } \\
\text { environment } \\
\text { (in group) }\end{array}$ & $\begin{array}{l}\text { are spoken } \\
\text { at home, } \\
\text { hostel, } \\
\text { social } \\
\text { environme } \\
\text { nt (in } \\
\text { group) }\end{array}$ & $\begin{array}{l}\text { are limited } \\
\text { in } \\
\text { communicat } \\
\text { ion between } \\
\text { parents }\end{array}$ & $\begin{array}{l}\text { are limited } \\
\text { in } \\
\text { communicat } \\
\text { ion between } \\
\text { parents }\end{array}$ & $\begin{array}{l}\text { are limited } \\
\text { in } \\
\text { communica } \\
\text { tion } \\
\text { between } \\
\text { parents }\end{array}$ & $\begin{array}{l}\text { are limited } \\
\text { in } \\
\text { communicat } \\
\text { ion between } \\
\text { parents }\end{array}$ \\
\hline \multirow[t]{2}{*}{ Ideology } & - Catholic & & - Protestant & - Protestant & - Protestant & - Protestant \\
\hline & $\begin{array}{l}\text { - Identity } \\
\text { Tribal }\end{array}$ & $\begin{array}{l}\text { Protestant } \\
\text { - Identity } \\
\text { Tribal }\end{array}$ & $\begin{array}{l}\text { Understandi } \\
\text { ng, attitude, } \\
\text { behavior of } \\
\text { Papua } \\
\text { diversity }\end{array}$ & $\begin{array}{l}\text { - } \\
\text { Understandi } \\
\mathrm{ng} \text {, attitude, } \\
\text { behavior of } \\
\text { Papua } \\
\text { diversity }\end{array}$ & $\begin{array}{l}\text { - } \\
\text { Understan- } \\
\text { ding, } \\
\text { attitude, } \\
\text { behavior of } \\
\text { Papua } \\
\text { diversity }\end{array}$ & $\begin{array}{l}\text { - } \\
\text { Understandi } \\
\text { ng, attitude, } \\
\text { behavior of } \\
\text { Papua } \\
\text { diversity }\end{array}$ \\
\hline \multirow[t]{2}{*}{ Symbols } & Cenderawas & Cenderaw & Cenderawas & Cenderawasi & Cenderawa & Cenderawas \\
\hline & $\begin{array}{l}\text { ih bird, } \\
\text { Honay, } \\
\text { Noken, } \\
\text { Batik } \\
\text { Papua, } \\
\text { Hipere }\end{array}$ & $\begin{array}{l}\text { asih bird, } \\
\text { Noken, } \\
\text { Batik } \\
\text { Papua }\end{array}$ & $\begin{array}{l}\text { ih bird } \\
\text { Noken, Tifa, } \\
\text { Honai, Batik } \\
\text { Papua }\end{array}$ & $\begin{array}{l}\text { h bird, Batik } \\
\text { Papua, } \\
\text { Papeda }\end{array}$ & $\begin{array}{l}\text { sih bird, } \\
\text { Batik } \\
\text { Papua }\end{array}$ & $\begin{array}{l}\text { ih bird, Tifa, } \\
\text { Ondoafi, } \\
\text { Papeda, } \\
\text { Batik Papua }\end{array}$ \\
\hline
\end{tabular}

The second is the Multicultural Category attached to Nancy, Nando, Obed, and Richard. From the ethnic aspect, Nancy comes from the Manokwari-Biak, Nando from Ayamaru (Meybrat/Sorong), Obed from Bonggo/Sarmi, and Richard from Port Numbay/ Jayapura. The four students are from the Melanesian race which is the original Papuan race. The local language is used is limited in communication between parents (family). Meanwhile, ideologically, the four students are Protestant. In the four students grew understanding, attitudes, behavior diversity of Papua. The symbol attached to the students is the use of Papuan batik cloth as one of the official school uniforms in Jayapura. Other known symbols are bird of paradise, ondoafi, Raja Ampat, Puncak Kartenz, National Hero of Indigenous Papuan, and Papuan special food that is papeda.

\subsection{Papuan-ness Mixed High School Students in Jayapura}

Papuan-ness Mixed High School Students in Jayapura based on five indicators or capital (ethnics, races, language, ideology and symbols) are grouped into two categories: (1) Local Identity (Ethno-Nationalism), and (2) Multicultural. 
Table 2 Papuan-ness Mixed High School Students in Jayapura

\begin{tabular}{|c|c|c|c|c|c|c|}
\hline \multirow{3}{*}{ INDICATOR } & \multicolumn{6}{|c|}{ CATEGORY } \\
\hline & & $\begin{array}{c}\text { Local Identity } \\
\text { (Ethno-Nationalism) }\end{array}$ & & & Multicultural & \\
\hline & Cintya & Nissa & Stefan & Nana & Rahmat & Tantri \\
\hline Ethnics & Biak- Makassar & $\begin{array}{l}\text { Sorong/Jawa- } \\
\text { Manado }\end{array}$ & Wamena-Jawa & $\begin{array}{l}\text { Padang/Palem- } \\
\text { bang-Biak }\end{array}$ & $\begin{array}{l}\text { Bugis- } \\
\text { Kaimana/Bugis/ } \\
\text { China }\end{array}$ & $\begin{array}{l}\text { Biak/Ternate- } \\
\text { Jawa/Sunda }\end{array}$ \\
\hline Races & $\begin{array}{l}\text { Melanesian - } \\
\text { Austronesian }\end{array}$ & $\begin{array}{l}\text { Melanesian } \\
\text { Austronesian }\end{array}$ & $\begin{array}{l}\text { Melanesian- } \\
\text { Austronesian }\end{array}$ & $\begin{array}{l}\text { Austronesian- } \\
\text { Melanesian }\end{array}$ & $\begin{array}{l}\text { Austronesian- } \\
\text { Melanesian- } \\
\text { Yellow race }\end{array}$ & $\begin{array}{l}\text { Austronesian- } \\
\text { Melanesian }\end{array}$ \\
\hline Language & $\begin{array}{l}\text { Regional } \\
\text { languages are } \\
\text { limited in } \\
\text { communication } \\
\text { between parents } \\
\text { and children }\end{array}$ & $\begin{array}{l}\text { Regional } \\
\text { languages are } \\
\text { limited in } \\
\text { communication } \\
\text { between parents } \\
\text { and children }\end{array}$ & $\begin{array}{l}\text { Regional } \\
\text { languages are } \\
\text { not used at } \\
\text { home }\end{array}$ & $\begin{array}{l}\text { Regional } \\
\text { languages are } \\
\text { limited in } \\
\text { communication } \\
\text { between parents } \\
\text { and children }\end{array}$ & $\begin{array}{l}\text { Regional } \\
\text { languages are } \\
\text { not used at } \\
\text { home }\end{array}$ & $\begin{array}{l}\text { Regional } \\
\text { languages are } \\
\text { not used at } \\
\text { home }\end{array}$ \\
\hline Ideology & $\begin{array}{l}\text { - Protestant } \\
\text { - Identity } \\
\text { tribal }\end{array}$ & $\begin{array}{l}\text { - Protestant } \\
\text { - Identity } \\
\text { tribal }\end{array}$ & $\begin{array}{l}\text { - Protestant } \\
\text { - Identity } \\
\text { tribal }\end{array}$ & $\begin{array}{l}\text { - Protestan } \\
\text { - Understanding, } \\
\text { attitude, behavior } \\
\text { of Papua } \\
\text { diversity }\end{array}$ & $\begin{array}{l}\text { - Islam } \\
\text { - Understan- } \\
\text { ding, attitude, } \\
\text { behavior of } \\
\text { Papua diversity }\end{array}$ & $\begin{array}{l}\text { - Islam } \\
\text { - Understan- } \\
\text { ding, attitude, } \\
\text { behavior of } \\
\text { Papua diversity }\end{array}$ \\
\hline Symbols & $\begin{array}{l}\text { Cenderawasih } \\
\text { bird, Batik } \\
\text { Papua }\end{array}$ & $\begin{array}{l}\text { Cenderawasih } \\
\text { bird, Batik Papua }\end{array}$ & $\begin{array}{l}\text { Cenderawasih } \\
\text { bird, Batik } \\
\text { Papua }\end{array}$ & $\begin{array}{l}\text { Cenderawasih } \\
\text { bird,, Batik Papua }\end{array}$ & $\begin{array}{l}\text { Cenderawasih } \\
\text { bird, Batik } \\
\text { Papua, Honai, } \\
\text { Arc, Arrow, } \\
\text { Tifa, Mountain, } \\
\text { Jayawijaya }\end{array}$ & $\begin{array}{l}\text { Cenderawasih } \\
\text { bird,, Batik } \\
\text { Papua, Puncak } \\
\text { Kartenz, Raja } \\
\text { Ampat, and } \\
\text { Asmat }\end{array}$ \\
\hline
\end{tabular}

Based on Table 2, The first is the Local Identity Category or Ethno-Nationalism attached to Cintya, Nissa \& Stefan. From the ethnic aspect, Cintya is a mixture of ethnic Sorong/Java with Manado; Nissa is a mixture of ethnic Biak with Makassar; and Stefan is a mixture of ethnic Wamena with Java. In the context of mixed marriages there are several patterns, namely marriage patterns between indigenous Papuan men and non Papuan women or migrants - as in the case of Nissa (Biak-Makassar) and Stefan (Wamena-Java). Next, the pattern of marriage between mixed Papuan and non-Papuan (father) married to non-Papuan women (mothers) - as in the case of Cintya (Sorong /Java-Manado). Meanwhile, from the aspect of race, the three students are a mixture of the Melanesian-Austronesian race. In family communication, local language is used limited between parents and children. Ideologically, the three students are Protestant. The construction of the local identity of the three students is a tribal thickness such as values, and local traditions. In the three students attach Papuan batik symbols that are worn as uniforms on a certain day each week based on the discipline of each school. The other Papuan symbols such as: cenderawasih bird, honay, arrow, bow, tifa, about geographical location: mountains and Jayawijaya.
The second is the Multicultural Category, which is attached to the self Nana, Rahmat and Tantri. From the ethnic aspect, Nana is a mixture of marriage patterns between nonPapuan (father: Padang/Palembang) with Papuan women (Biak). Meanwhile, Tantri, following the pattern of marriage between a mixed father of Papua and non-Papuan (BiakTernate) who married non-Papuan women (Java-Sunda). Furthermore, Rahmat, the result of a marriage between a non-Papuan father (Bugis) who is married to a mother (mix: Kaimana-Bugis-China). However, the three students still use the name of the Papuan clan including non-Papuan fathers. As for race indicator, Tantri is the result of marriage between Melanesian-Austronesian race and Austronesian race. Nana is the result of marriage between the Austronesian race and the Melanesian race. Meanwhile, Rahmat, the result of a more complex race mixing of Melanesia-Austronesian-Yellow race. In the three students that regional language is not used in the family. From the aspect of ideology, Nana is Protestant, while Rahmat and Tantri are Muslims. In the three students have formed understanding, attitude, behavior diversity of Papua. Meanwhile, the symbols inherent in the daily practice of students are batik Papua which is designated as school uniform. The most familiar symbol of the three 
students is the Cenderawasih Bird that is only present in the Land of Papua. Other symbols are Honai, Bows, Arrows, Tifa, Mount Cartenz, Wamena, Jayawijaya, Raja Ampat, and Asmat.

\section{Conclusion}

There were two categories of Papuan-ness identity of the high school students in Jayapura: Local Identity (Ethno-Nationalism) and multicultural. Local Papuan identity (Papuan-ness) is important to be developed in High School students. Growing Papuan-ness can strengthen the national identity (Indonesian-ness). The fact that Indonesian nationalism is made up of a collection of local nationalism (ethno-nationalism).

\section{References}

Adib, M. (2012). Agen dan Struktur dalam Pandangan Piere Bourdieu. Jurnal BioKultur, 1(2): 91-110.

Afwan, B. A. (2015). Mutiara Terpendam Papua: Potensi Kearifan Lokal untuk Perdamaian di Tanah Papua. Yogyakarta: Sekolah Pascasarjana UGM.

Agung, L. S. (2014). Pengembangan Model KKBB Sebagai Upaya Peningkatan Kualitas Pembelajaran Sejarah SMA Di Solo Raya. Jurnal Paramita, 24(1), 126136.

Anwar, R \& Cangara, H. (2016). Rintangan Komunikasi Antar Budaya dalam Perkawinan dan Perceraian Etnis Jawa dengan Papua di Kota Jayapura (Suatu Strategi Manajemen Konflik dalam Hubungan Interpersonal Pasangan Suami Istri). Jurnal Komunikasi Kareba, 5(2), 273-285.

Bourdieu, P. (2016). Arena Produksi Kultural: Sebuah Kajian Sosiologi Budaya. Yogyakarta: Kreasi Wacana.

Creswell, J.W. (2014). Research Design: Pendekatan Kualitatif, Kuantitatif, dan Mixed. Yogyakarta: Pustaka Pelajar.

Harker, R., Mahar, C., \& Wilkes, C (Ed.), (2009). (Habitus $\times$ Modal) + Ranah $=$ Praktik: Pengantar Paling Komprehensif kepada Pemikiran Pierre Bourdieu. Yogyakarta: Jalasutra.

Nafi'ah, U., \& Utami, I.W.P. (2017). Development of Sigil Based E-Book As Media for "Technology and Information for History Learning" Course". Paramita: Historical Studies Journal, 27(1), 103-112.

Pamungkas, C. (2015). Sejarah Lisan Integrasi Papua Ke Indonesia: Pengalaman Orang Kaimana Pada Masa Trikora dan Pepera. Jurnal Paramita, 25(1), 88-108.

Pamungkas, C. (2016). Muslim Papua dan Muslim Pendatang Pertarungan Identitas Antara Ke-Indonesia-an dan Kepapuaan. Jurnal Kawistara (6)3, 225-324.

Pramono, S.E. (2012). Perbaikan Kesalahan Konsep Pembelajaran Sejarah Melalui Metode Pemecahan Masalah dan Diskusi. Jurnal Paramita, 22(2), 238248.

Putro, H.P.N. (2012). Model Pembelajaran Sejarah Untuk Meningkatkan Kesadaran Sejarah Melalui Pendekatan Inkuiri. Jurnal Paramita, 22 (2), 207-216.

Schunk, D. H. (2012). Learning Theories An Educational Perspective. Diterjemahkan oleh Eva Hamdiah dan Rahmat Fajar. Teori-Teori Pembelajaran: Perspektif Pendidikan. Yogyakarta: Pustaka Pelajar.

Setyawan, D. (2017). "Gerakan Intelektual Kolektif Komunitas \#Ayokedamraman dalam Pemberdayaan Warga Membangun Pariwisata Alam dan Ekonomi Kreatif”. Jurnal Nizham, 5(2), 15-28.

Supriatna, N. (2012). Penggunaan Konsep Ilmu Sosial Dalam Konstruksi Pembelajaran Sejarah Kritis. Jurnal Paramita, 22(1), 143-156.

Supriyono, J. (2014). "Diskursus Kolonialistik dalam Pembangunan di Papua: Orang Papua dalam Pandangan Negara". Jurnal Ultima Humaniora, (2)1, 59-78.

Suryani, N. (2013). Pengembangan Model Internalisasi Nilai Karakter Dalam Pembelajaran Sejarah Melalui Model Value Clarification Technique. Jurnal Paramita, 23(2), 208-219.

Sutiyah. (2013). Upaya Guru Sejarah Dalam Menyiasati Tuntutan Pemanfaatan ICT Dalam Pembelajaran Di SMA. Jurnal Paramita, 23(1), 114-125.

Sutrisna, E. (2012). Strategi Guru Dalam Pembelajaran IPS (Studi Eksploratif Pelaksanaan Pembelajaran IPS Di SMP - Wilayah Kabupaten Pati. Journal of Educational Social Studies (JESS), 1(1), 48-54. 
Trajano, J.C.I. L. (2010). Ethnic Nationalisme and Separatism in West Papua, Indonesia. Journal of Peace, Conflict and Development, Issue 16: 12-35.

Wahyuni, T. (2012). Implementasi Cooperative Learning Tipe Think-PairShare Pada Pembelajaran IPS. Journal of Educational Social Studies (JESS), 1(2), 118-124.
Widjojo, M. S. (Eds). (2009). Papua Road Map: Negotiating the Past, Improve the Present and Securing the Future. Jakarta: LIPI - Yayasan Tifa - Yayasan Obor Indonesia.

Zuhdi, S. (2017). Integrasi Bangsa Dalam Bingkai Keindonesiaan. Jakarta: Wedatama Widya Sastra. 